\title{
Enabling Environment and Agriculture in ECOWAS: Implications for Food Security
}

\author{
ROMANUS OSABOHIEN \\ Department of Economics and Development Studies \\ Centre for Economic Policy and Development Research (CEPDeR) \\ Covenant University \\ Km 10, Idiroko Road, Ota \\ NIGERIA \\ ISAIAH O. OLURINOLA \\ Department of Economics and Development Studies \\ Covenant University \\ Km 10, Idiroko Road, Ota \\ NIGERIA \\ OLUWATOYIN A. MATTHEW \\ Department of Economics and Development Studies \\ Centre for Economic Policy and Development Research (CEPDeR) \\ Covenant University \\ Km 10, Idiroko Road, Ota \\ NIGERIA
}

\author{
AMECHI ENDURANCE IGHARO \\ Department of Economics \\ Usmanu Danfodiyo University \\ Sokoto \\ NIGERIA
}

\begin{abstract}
This study examined how enabling environment (proxied by political stability and absence of violence) affect agricultural production and food security in the Economic Community of West African States (ECOWAS) sub-region. The essence of this study is to ensure that a conducive enabling environment is put in place to boost agriculture, so as to ensure food security in ECOWAS sub-region. The study employed the fixed and random effects econometric method on the data sourced from the World Development Indicators (WDI) and the Food and Agricultural Organisation (FAO) for the period 2000 to 2018. The findings from the study showed that, when there is an enabling environment for farming, agriculture production increased by $1 \%$, while food security increased by about $3 \%$.These findings imply that proper policies and programmes should be put in place towards ensuring an enabling environment for agricultural activities which will increase production and food security within the ECOWAS sub-region.
\end{abstract}

Keywords: -Institutions, Governance, Political Stability, Farming

Received: April 4, 2020. Revised: November 30, 2020. Accepted: December 24, 2020. Published: January 22, 2021.

\section{Introduction}

The enabling environment - political stability, peace and absence of violence in a system can have a significant effect on the viability and productivity of such a system [1],[2],[3],[4]. The agricultural system is not an exception, as enabling environment significantly impact on the viability and productivity of the agricultural system which affects food security in return [5]. On the other hand, absence of peace, unstable policies and regulations can derail even the best business plans, leading to losses and setbacks, the scaling back of agricultural investment thereby leading to low production and food insecurity [5]. 
Without an enabling environment, agricultural activities will be disrupted which will negatively affect production and in turn, food system. For example, farmer-herder conflict and communal conflict in most West African countries, especially the Northern part of Nigeria has led to displacement, infrastructural damages amongst others, and has greatly constrained access to farming land and harvest losses [5]. Most of the households affected by conflicts lost their livelihoods and are mainly dependent on humanitarian assistance from the US Agency for International Development (USAID) [5].

In this study, we seek to assess how enabling environment proxied by political stability and absence of violence (environmental peace) affect agricultural production which in turn affect food security in the ECOWAS sub-region, in order to contribute to the argument in the body of literature. The reason for this is because; agricultural production needs to be enhanced to achieve food security. In recent times, global agricultural production has not been able to keep pace with the population growth rate, mainly due to the increase in environmental disruption [8]. Also, irrespective of the global gains in agricultural production, access to food remains unequally distributed, especially in developing regions of the world. As a result of this uneven distribution of food, about 870 million individuals lack access to sufficient food required to maintain a healthy life with many more suffering from 'hidden hunger' caused by protein deficiencies [5],[6],[7],[8],[9].

Food security simply means a situation where all people, at all times, have physical, social and economic access to sufficient, safe, and nutritious food that meets their dietary needs and food preferences for active and healthy life [9]. Food security goes beyond availability; it includes the ability to possess monetary and non-monetary resources by the population to gain access to adequate quantities and qualities of food [10], [11]. One of the major ways to ensure food security is to engage in agriculture, this will help sustain and increase agricultural production that will feed the teeming population [12].

Food security is one of the recent major threats confronting the world. Food security is inter-linked with other current global challenges of the economy, weather and climatic change. The best way of determining the sufficiency of food is when households, at every given time, can afford; safe, sufficient and energy-given food that meets their daily need of food consumption. This connotes enhancing households' entitlements to food [5],[13] [14],[15].

Although, there are efforts made at the global level in ensuring food security, but food insecurity persist at the household level and millions of people are still vulnerable due to different shocks and stress experienced in the environment which they live in [14].This accounts for the motivation behind this study. It is against this backdrop that this study sets out to evaluate the role of an enabling environment in enhancing agricultural production and food security in the Economic Community of West African States (ECOWAS) sub-region. Hence, this study comprises of five sections; following this introductory section is section two which presents some insights from the empirical literature. Section three focuses on the method engaged in the study; section four discusses the empirical analysis of the findings of the study; section five concludes the study by recommending policies that will help turn around the issues associated with creating the enabling environment that will encourage agriculture and food security in ECOWAS.

\section{Problem Formulation}

\subsection{Literature Review}

Agriculture is the major activity in most of the West African countries, which constitutes about $60 \%$ of the total employment rate in the region in 2009 [15],[16],[17],[18]. Despite the importance of agriculture in Africa, employment in the sector has reduced to 54 percent in 2016 because young people are not motivated enough to participate in agriculture as an occupation. Though, agricultural performance has been declining globally, the sector dominates the West African economies [17]. The agricultural sector in developing countries contributes significantly to the overall growth of their economies, and unarguably, agricultural development has special potentials for employment generation and poverty reduction [14]

The study of Osabohien et al.[1] using the partial equilibrium approach and trader profit-maximisation to model to examine productivity level and the prevalence of marketing and demand constraints among banana growers in Nigeria and found that increased supply relative to demand reduces grower returns which in turn affect food security. It has also been noted that each unit increase in agricultural 
activity leads to approximately 1.5 units in household welfare and livelihood, which shows the importance of agriculture to the economy [14]. Some studies have also noted the positive relationship between economic growth, agriculture productivity and food security

In West Africa, the agricultural sector contributes more than 35\% to the Gross Domestic Product-GDP [15]. However, the practice of agriculture in this region has largely remained unattractive to the people, especially the youths for various reasons which include; no prospect, low returns and input investments, limited access to land, low investments in infrastructure necessary for efficient value chains According to FAO [7], 1.3 billion people engage in various forms of agriculture around the world to increase production and ensure food security, 97 percent of these people are from the developing countries; depending on the region, $30 \%$ to 50 percent of household income in rural regions is generated directly from agriculture. Agriculture has great potential to provide an essential contribution to employment for the unemployed and reduce poverty among rural farmers because when people are employed, they will have a source of livelihood and will be able to cater for themselves and their dependants.

Production sustainability is another important facet of food security. It means that food production has to carry on upholding with the demand for future generations [18]. The reality shows that the average yearly growth rate of some major crops has declined across the globe [18]. For example, rice yield declined from $2.42 \%$ in $1974-1982$ to $1.78 \%$ in 1982-1990 [19]. In Asia, the corresponding figures were $2.62 \%$ to $1.66 \%$ and in China $4 \%$ to $1.6 \%$. It also shows similar pictures for other crops like maize, wheat, sorghum and other staple food grains [19],[21],[22]. This is in line with the study of Nagarajan et al. [19] using the two-stage least squares found that policy instability negatively affected maize yields in Kenya.

Food security, as well as its sustainability, depends on some physical, social, economic and political factors both countrywide and worldwide [34]. Some important socio-economic factors are population growth, demographic changes, rapid urbanisation and income growth on the demand side as well as technological development and agricultural productivity growth on the supply side, may encompass a significant role in the progress of world food scenario [23].
Agricultural productivity growth can be a significant instrument for reducing poverty and achieving food security in developing countries [24]. In this case, the fact is that the linkage between traditional (agricultural) and modern (industrial) sectors is more important for reducing poverty in developing countries. It is also essential to prioritise small and medium-sized farmers, who prefer to use domestically produced goods and services rather than large scale farmers [25]. Moreover, the development strategy of developing countries should be agriculture-driven rather than exportoriented and that increased productivity in agriculture may be the initiator of industrialization [32]. However, the extent of these effects in reducing poverty depends on the specific situation in an economy [20],[26].

Some authors have argued that there is a positive correlation between agricultural GDP growth and non-agricultural GDP growth in developing countries. Bravo-Ortega and Lederman [27] also agree about the positive relationship between them, but they argued that this relation is reverse for developed and industrialized countries and there are also regional differences. Other factors such as openness of the economy may change the relationship between agricultural growth and nonagricultural growth. This is because global markets interfere in agricultural growth by providing international capital flows and through food imports [24]. Hence, it is clear that the significance of linkages between the agricultural sector and the rest of the economy differs across the countries.

Agricultural productivity growth is positively correlated with lower food prices, better nutritional intake and increased capital flow from agriculture [28]. Osabohien et al. [29] confirmed Timmer's findings and find a positive relationship between different agricultural productivity measures and average real GDP growth. Therefore, it may increase employers' productivity as well as may improve the rural household's food security. Absolute and relative poverty have reduced with higher farm productivity in West Africa [30]. The direct and indirect effects of agricultural productivity growth reduce poverty in developing countries [31].

Christiansen and Demery [32] estimated that a 1 percent per capita agricultural growth may reduce poverty 1.6 times more than the similar growth in industry and 3 times in the service sector. Therefore, 
it is observed that agricultural growth in developing countries is a vital mechanism for helping the very poor. From this perspective, increased agricultural productivity may not only contribute to poverty alleviation but also may improve the country's economy.

\section{Problem Solution Methodology}

The econometric model for this study is hinged on the empirical study of Ujunwa et al. [14]. In the study, it was argued that a strong institutional framework and agricultural production can lead to food security which forms the baseline for this study. The study employed the fixed and random effects regression model to examine how enabling environment affect agricultural production and food security in the ECOWAS sub-region. Thus, the baseline (implicit) model is given in equation (1), while the explicit (non-linear) form of the model is shown in equation (2);

$Y_{(k) i t}=f\left(E E N V_{i t}, A_{E M P_{i t}}, A_{E L E C T_{i t}}\right.$, POPGR $\left._{i t}\right)$

The implicit (non-linear) form of the model is specified in equation (2);

$Y_{(k) i t}=A * E E N V_{i t}^{{ }^{\sigma_{1}}} \cdot A E M P_{i t}^{{ }^{\sigma_{2}}} \cdot{ }^{2} \cdot A E L E C T_{i t}{ }^{\sigma_{3}} \cdot \varnothing_{4} P O P G R_{i t} \cdot e_{i t}$

Given the fact that equation (2) is a non-linear equation, which may be difficult to estimate, it is therefore linearised using the natural logarithm as shown in equation (3)

$Y_{(k) i t}=A+\emptyset_{1} \ln E E N V_{i t}+\varnothing_{2} \ln A E M P_{i t}+$

$\emptyset_{3} \ln A E L E C T_{i t}+\emptyset_{4}$ POPGR $\left._{i t}+e_{i t}\right)$

Let $A=\emptyset_{0}$, therefore, the model to be estimated is given in equation (4)

$Y_{(k) i t}=\emptyset_{0}+\emptyset_{1} \ln E E N V_{i t}+\emptyset_{2} \ln A E M P_{i t}+$ $\emptyset_{3} \operatorname{lnAELECT}_{i t}+\emptyset_{4}$ POPGR $_{i t}+e_{i t}$

\section{Results}

This section of the study presents the results obtained from the analysis using fixed and random effects regression model. To know the suitability of
$\mathrm{Y}$ is the dependent variable. In this study, given the objective, two dependent variables (food security and agricultural production), denoted by $\mathrm{k}$. EENV represents enabling environment proxied by political stability and absence of violence which is the key independent variable, AEMP represents agricultural employment ( $\%$ of total employment) ELECT represents access to electricity (\% total population), and POPGR represents the growth rate of population (rate), $i$ represents entities which are the 15 ECOWAS countries included in the study which are: Benin, Burkina Faso, Cape Verde, Cote d'Ivoire, Gambia, Ghana, Guinea, Guinea Bissau, Liberia, Mali, Mauritania, Nigeria, Senegal, Sierra Leone and Togo). There are sixteen ECOWAS countries; Niger was excluded due to missing observations of some of the variables of interest. From the model, $\mathrm{t}$ represents period covered by the study (2000 - 2018), $\ln$ represents natural logarithm transformation, $\emptyset_{0}$ represents the constant term, $\emptyset_{1}, \emptyset_{2}, \varnothing_{3}$ and $\varnothing_{4}$ are the coefficients of the independent variables, while $\mathrm{e}$ represents the random term.

The 'apriori' expectation is that the independent variable enabling environment proxied by political stability and absence of violence, employment in the agricultural sector, access to electricity are expected to positively affect food security and agricultural production, while population growth rate is expected to negatively affect food security and agricultural production. According to FAO [7], food security is said to exist when all household members at any given point in time can access adequate, staple and nutritious food required for a healthy life. There are four major aspects of food security, namely: availability, accessibility, utilisation and stability. This study engaged the accessibility component of food security which is proxied by gross domestic per capita, purchasing power parity (PPP) (constant $\$ 1$ per person).

the fixed and random effects model, the 'Hausman' test was conducted. Therefore, the estimated outcomes from the fixed and random effects regression model are presented in Table 1.

As earlier stated, there are four major dimensions of food security viz; availability, accessibility, utilisation, and stability; each of the four dimensions has its unique components as a measure of food 
security [33], [34]. Though, the four dimensions of food security are highly important, in this study, given the peculiarity of the economy of our study, we considered accessibility component of food security proxied by GDP per capita $1 \$$ per person. The main reason for focusing on the accessibility component of food security is because production alone may not guarantee food security when households have no access to the food produced. Access is ensured when all households have enough resources to obtain food in sufficient quantity, quality and diversity for a nutritious diet which depends mainly on the number of household resources and changing market conditions [34]. The result obtained from the econometric model is $\begin{array}{lll}\text { presented } & \text { in } & \text { Table }\end{array}$

Table 1: Fixed and Random Effects Results

\begin{tabular}{|c|c|c|c|c|c|c|c|c|}
\hline \multirow{3}{*}{ Variable } & \multicolumn{4}{|c|}{ Food Security } & \multicolumn{4}{|c|}{ Agricultural production } \\
\hline & \multicolumn{2}{|c|}{ Main Regression } & \multicolumn{2}{|c|}{ robustness check } & \multicolumn{2}{|c|}{ Main Regressions } & \multicolumn{2}{|c|}{ Robustness checks } \\
\hline & $\begin{array}{l}\text { Fixed } \\
\text { Effect }\end{array}$ & $\begin{array}{r}\text { Random } \\
\text { Effect }\end{array}$ & $\begin{array}{l}\text { Fixed } \\
\text { Effect }\end{array}$ & $\begin{array}{l}\text { Random } \\
\text { Effect }\end{array}$ & $\begin{array}{l}\text { Fixed } \\
\text { Effect }\end{array}$ & $\begin{array}{l}\text { Random } \\
\text { Effect }\end{array}$ & $\begin{array}{l}\text { Fixed } \\
\text { Effect }\end{array}$ & $\begin{array}{r}\text { Random } \\
\text { Effect }\end{array}$ \\
\hline & [1] & [2] & [3] & [4] & [5] & [6] & [7] & [8] \\
\hline Constant & $\begin{array}{l}0.74 \\
(3.27) \\
{[0.82]}\end{array}$ & $\begin{array}{c}0.62^{\mathrm{b}} \\
(2.49) \\
{[0.01]}\end{array}$ & $\begin{array}{l}5.27^{\mathrm{a}} \\
(0.69) \\
{[0.00]}\end{array}$ & $\begin{array}{l}2.62^{\mathrm{c}} \\
(2.43) \\
{[0.02]}\end{array}$ & $\begin{array}{l}11.38^{\mathrm{a}} \\
(0.9) \\
{[0.00]}\end{array}$ & $\begin{array}{l}10.99^{a} \\
(0.80) \\
{[0.00]}\end{array}$ & $\begin{array}{l}11.38^{\mathrm{a}} \\
(0.60) \\
{[0.00]}\end{array}$ & $\begin{array}{l}11.38^{a} \\
(0.60) \\
{[0.00]}\end{array}$ \\
\hline Agricultural Production & $\begin{array}{l}0.20^{\mathrm{c}} \\
(0.09) \\
{[0.02]}\end{array}$ & $\begin{array}{l}0.34^{\mathrm{a}} \\
(0.09) \\
{[0.00]}\end{array}$ & $\begin{array}{l}0.20^{\mathrm{c}} \\
(0.07) \\
{[0.03]}\end{array}$ & $\begin{array}{l}0.34^{\mathrm{a}} \\
(0.10) \\
{[0.00]}\end{array}$ & - & - & - & - \\
\hline Agricultural employment & $\begin{array}{l}0.15 \\
(0.18) \\
{[0.39]}\end{array}$ & $\begin{array}{l}0.48^{\mathrm{a}} \\
(0.14) \\
{[0.00]}\end{array}$ & $\begin{array}{l}0.06 \\
(0.15) \\
{[0.44]}\end{array}$ & $\begin{array}{l}0.48^{a} \\
(0.17) \\
{[0.00]}\end{array}$ & $\begin{array}{l}0.18^{a} \\
(0.21) \\
{[0.00]}\end{array}$ & $\begin{array}{c}0.08^{a} \\
(0.18) \\
{[0.00]}\end{array}$ & $\begin{array}{c}0.18^{a} \\
(0.15) \\
{[0.00]}\end{array}$ & $\begin{array}{l}0.18^{a} \\
(0.15) \\
{[0.00]}\end{array}$ \\
\hline Enabling environment & $\begin{array}{l}0.03^{\mathrm{a}} \\
(0.01) \\
{[0.00]}\end{array}$ & $\begin{array}{l}0.03^{\mathrm{a}} \\
(0.01) \\
{[0.00]}\end{array}$ & $\begin{array}{l}0.03^{\mathrm{a}} \\
(0.01) \\
{[0.00]}\end{array}$ & $\begin{array}{l}0.03^{\mathrm{c}} \\
(0.02) \\
{[0.09]}\end{array}$ & $\begin{array}{l}0.01^{\mathrm{a}} \\
(0.01) \\
{[0.00]}\end{array}$ & $\begin{array}{l}0.01^{\mathrm{a}} \\
(0.01) \\
{[0.00]}\end{array}$ & $\begin{array}{l}0.01^{\mathrm{a}} \\
(0.01) \\
{[0.00]}\end{array}$ & $\begin{array}{l}0.01^{\mathrm{a}} \\
(0.01) \\
{[0.00]}\end{array}$ \\
\hline Access to electricity & $\begin{array}{l}0.36^{\mathrm{a}} \\
(0.05) \\
{[0.00]}\end{array}$ & $\begin{array}{l}0.38^{\mathrm{a}} \\
(0.05) \\
{[0.00]}\end{array}$ & $\begin{array}{l}0.36^{\mathrm{a}} \\
(0.12) \\
{[0.00]}\end{array}$ & $\begin{array}{l}0.38^{\mathrm{a}} \\
(0.09 \\
{[0.00]}\end{array}$ & $\begin{array}{c}0.14^{\mathrm{b}} \\
(0.07) \\
{[0.05]}\end{array}$ & $\begin{array}{l}0.14^{\mathrm{b}} \\
(0.07) \\
{[0.05]}\end{array}$ & $\begin{array}{l}0.14^{\mathrm{b}} \\
(0.07) \\
{[0.05]}\end{array}$ & $\begin{array}{l}0.14^{b} \\
(0.07) \\
{[0.05]}\end{array}$ \\
\hline Population growth rate & $\begin{array}{l}-0.44^{\mathrm{a}} \\
(0.06) \\
{[0.00]}\end{array}$ & $\begin{array}{l}-0.46^{\mathrm{a}} \\
(0.07) \\
{[0.00]}\end{array}$ & $\begin{array}{l}-0.44^{\mathrm{a}} \\
(0.06) \\
(0.00)\end{array}$ & $\begin{array}{l}-0.46^{\mathrm{a}} \\
(0.05) \\
{[0.00]}\end{array}$ & $\begin{array}{l}-0.16 \\
(0.10) \\
{[0.10]}\end{array}$ & $\begin{array}{l}-0.17^{\mathrm{a}} \\
(0.09) \\
{[0.00)}\end{array}$ & $\begin{array}{l}-0.16^{\mathrm{a}} \\
(0.04) \\
{[0.00]}\end{array}$ & $\begin{array}{c}-0.16^{\mathrm{a}} \\
(0.04) \\
{[0.00]}\end{array}$ \\
\hline Year Dummies & No & No & No & No & No & No & No & No \\
\hline Country Dummies & No & No & No & No & No & No & No & No \\
\hline Prob $>\mathrm{F}$ & 0.0000 & 0.0000 & 0.0000 & 0.0000 & 0.0000 & 0.0000 & 0.0000 & 0.0000 \\
\hline Robust S.E & No & No & Yes & Yes & Yes & Yes & No & No \\
\hline $\begin{array}{l}\text { R-squared } \\
\text { Overall }\end{array}$ & 0.85 & 0.95 & 0.85 & 0.95 & 0.50 & 0.50 & 0.50 & 0.50 \\
\hline $\begin{array}{l}\text { Observation } \\
\text { Hausman Test } \\
\text { Prob>chi } 2\end{array}$ & 63 & 63 & 63 & 63 & $\begin{array}{l}63 \\
0.8641\end{array}$ & 63 & 63 & \\
\hline
\end{tabular}

Source: Authors' Computation, 2020. Note: the standard errors and the probability values are in parentheses () and [] respectively, while $\mathrm{a}, \mathrm{b}$ and $\mathrm{c}$ means that the coefficients are significant at $1 \%, 5 \%$ and $10 \%$ respectively.

Food security model, result obtained from the fixed and random effects model which is presented in Table 1 showed that the key variable in this study (enabling environment) proxied by political stability and absence of violence has the potential of increasing food security in ECOWAS by $1 \%$ and $3 \%$ respectively; agricultural employment can increase food security by $15 \%$ and $44 \%$ respectively. On the other hand, the population growth rate was observed to reduce food security by about $44 \%$ and $17 \%$ respectively. Agricultural production increase food security by $20 \%$ and $34 \%$ respectively. This result implies that enabling environment enhances households' ability to produce thereby ensuring access to food which will eventually lead to food security. From the model, the Probability value of 0.0000 (prob $>\mathrm{F}=0.0000$ ) shows that, jointly, exogenous variables in the model are significant in explaining the level of food security in ECOWAS.

Enabling environment such as political stability and absence violence in a system has the potential of affecting productivity in such a system [2], [1]. This 
is because; distortion of enabling environment may have a destructive effect on the ability of the poor households to raise income in both agricultural and non-agricultural sector and thereby reducing their purchasing power [26].

In agricultural production model, employment in agriculture, enabling environment and electricity supply were all significant in explaining the level of agricultural production in ECOWAS. This implies that, a 1percent increase in employment in agriculture, enabling environment and electricity supply may increase agricultural production by 0.18percent, 0.01percent and 0.07percent respectively. On the contrary, population growth rate, though significant, but negatively related to agricultural production in ECOWAS. This means that increased population growth in ECOWAS has the tendency of lowering agricultural production by 0.16 percent. This supports the finding the study by Matthew et al. [18] who found out that a negative relationship between population growth and agricultural output in the West African sub-region.

Food insecurity has been argued to be caused mainly by economic and environmental factors such as crop failure, over-population and poor government policies in most developing countries; especially, African countries. This is in line with the result obtained in this study as enabling environment was found to be statistically significant and increased agricultural production by about 1percent and food security by about 3 percent respectively. Therefore, there is a need to collectively address the issue of food insecurity through appropriate policies to ensure food security in the ECOWAS sub-region. The findings in this study are akin to the findings of Osabohien et al. [4]

\section{Conclusion}

The motivation for this study stems from the fact that there is need to provide an adequate enabling environment in order to boost agriculture so as to ensure food security in Nigeria. The study has contributed to knowledge in this regard. This study examined among others how enabling environment proxied by political stability and absence of violence affect food security in ECOWAS subregion using the fixed and random effects regression model and found that enabling environment is statistically and economically significant in explaining the level of food security in the region. The results obtained showed that enabling environment positively contribute to food security by 3 percent, agricultural engagement proxied by using the autoregressive distributed lag model and Ujunwa et al. [14] using a GMM approach which found out that effective governance and strong institutions increase food security in Africa.

In a similar study, Devereux [35] posited that food security is achieved through three main pathways, namely; through production, exchange and transfers. According to Devereux [35], the efficiency of each of these three pathways need enabling environment through effective governance to efficiently coordinate future expectations; hence, it is expected that enabling environment and food security move in the same direction. The production of food, for example, requires farmers to make costly investments of labour and inputs long before any benefits can be reaped by harvest at a future date. Unfortunately, in the case of ECOWAS which is characterised by political instability, an uncertain future reduces the expected return of these tradeoffs. As a result, the potential of this pathway is reduced.

In developing countries, especially Africa, aside from political instability, another major factor posing a challenge to food security which is considered in this study is the population (as found in this study population growth rate reduce food security by 44percent). This is validated by the fact that an increased rate of population growth in most cases drive-up demand for food, which mainly leads to a marginal use of arable land and water. This scenario is often witnessed in the region such as ECOWAS, where there is insufficient agricultural technical known-how to stimulate food production and integrated policies that simultaneously tackles societal demands for food.

agricultural employment contributed $15 \%$ and $48 \%$ respectively to food security, while the population growth rate was found to reduce food security by $46 \%$. Different factors may cause political instability in the ECOWAS sub-region. Conflicts over-controlling land are perhaps the most common. Conflict over-controlling territory is the largest category of causes of inter-state and intra-state conflicts globally.

Food security is a major concern in global agriculture that needs a significant increase to be able to feed the expected growing world population. One way to feed an ever-increasing world population is to increase the local and regional food supply of each country through improving 
agricultural productivity and that may confirm the first element of food security namely the availability of food in achieving sustainable food security. Moreover, increasing productivity among small and marginal farmers can be an important instrument to guarantee food security in low income developing governance which will enable farmers to increase production thereby leading to food security in ECOWAS, while future studies should examine how inter-state and intra-state conflicts affect food security in the ECOWAS sub-region countries in the long-run. Therefore, the study concludes that countries characterised by political insecurity and instability will continue to experience issues relating to food security.

Therefore, based on the findings of this study, the following recommendations are made. First, the governments of ECOWAS countries shouldencourage more people especially the youths to engage in agricultural activities as this will help boost food security. Second, the government should also provide a conducive environment for the farmers to practice agriculture. An enabling environment can be in the form of political and economic stability, providing soft loans to the farmers and providing social protection for the farmers. Lastly, the growth rate of population in these ECOWAS countries should be reduced so that agricultural productivity will match the population, this way hunger among the people will be eliminated.

\section{References:}

[1] Osabohien R, Olurinola IO, Matthew OA, Agro-financing and Agricultural Output in Nigeria. Journal of Advanced Research in Law and Economics, Vol. XI, Issue 4(50), 2020, pp. 1262-1268. DOI:10.14505/jarle.v11.4(50).22

[2] Igharo AE, Osabohien R, Onyemariechi, GO, Ibidapo DT, Monetary policy transmission mechanism, the innovative banking system and economic growth dynamics in Nigeria, International Journal of Business Innovation and Research, Vol.21,No.1, 2020, 1-22. DOI: 10.1504/IJBIR.2020.104032.

[3]Kristin, F, Oehmke J, Building African agribusiness through trust and accountability, Journal of Agribusiness in Developing and Emerging Economies, Vol.9, No.1, 2018, pp.22-43 https://doi.org/10.1108/JADEE-01-2018-0005.
[4]Osabohien R, Osabuohien E, Urhie E, (2018), Food security, institutional framework and technology: Examining the nexus in Nigeria using ARDL approach. Current Nutrition and Food Science, Vol.14, No.2, 2018, pp.154-163.

[5]USAID, USAID Office of Food for Peace Food Security Country Framework for Madagascar FY2014-FY2019. Washington, DC, United States Agency, 2018.

[6] Yoshida N, Local institutions and global value chains: development and challenges of shrimp aquaculture export industry in Vietnam, Journal of Agribusiness in Developing and Emerging Economies, Vol.4, No.2, 2016, pp.12-25, https://doi.org/10.1108/ JADEE-06-2016-0043.

[7] Food and Agricultural Organisation-FAO, The State of Food Insecurity in the World: Strengthening the Enabling Environment for food security nutrition, 2015. Accessed on October 20, 2019.

[8] Royal Society, Reaping the Benefits: Science and the Sustainable Intensification of Global Agriculture, London: McGraw Hill, 2009.

[9] Food and Agricultural Organisation-FAO, World agriculture: Towards 2015/2030.FAO Corporate Document Repository, 2017, pp.4-8.

[10] Matthew O, Adeniji A, Osabohien R, Olawande T, Atolagbe T, Gender Inequality, Maternal Mortality and Inclusive Growth in Nigeria, Social Indicators Research, Vol.147, No.3, 2020, pp. 763-780. DOI: https://doi.org/10.1007/s11205-019-02185-x.

[11] Osabohien R, Onanuga O, Aderounmu B, Matthew O, Osabuohien E, Social Protection and Employment in Africa's Agricultural Sector, Business: Theory and Practice, Vol.21, Issue 2, $2020 \quad$ pp. 494-502. https://doi.org/10.3846/btp.2020.11945. ISSN 1648-0627 /eISSN 1822-4202.

[12] Matthew OA, Owolabi OA, Osabohien R, Urhie E, Ogunbiyi T, Olawande TI, Edafe OD, Daramola PJ, Carbon Emissions, Agricultural Output and Life Expectancy in West Africa, International Journal of Energy Economics and Policy, Vol.10, Issue 3, 2020, pp. 489-496. https://doi.org/10.32479/ijeep.9177.

[13] Schmidhuber J, Tubiello FN, Global food security under climate change. Proceedings of the 
National Academy of Sciences, Vol.104, No.50, 2007, pp.19703-19708.

[14] Ujunwa A, Okoyeuzu C, Kalu EU, Armed conflict and food security in West Africa: socioeconomic perspective. International Journal of Social Economics, Vol.4, No.2, 2019, pp. 37-51.

[15] Feed the Future, Private Sector Voices: Building an Enabling Environment for Investment. Feed the Future Enabling Environment for Food Security Project, September 2018. Food and Agricultural Organization of the United Nations, Rome, 2018.

[16]Atinmo T, Adeniran T, Policy failure in the search for food security in Nigeria, European Journal of Sustainable Development, Vol.1,No.2, 1999, pp.199-220.

[17] Sileshi M, Kadigi R, Mutabazi K, Sieber S, Analysis of households' vulnerability to food insecurity and its influencing factors in East Hararghe, Ethiopia. Journal of Economic Structures, Vol.8, No.1, 2019, pp.41-52, doi:10.1186/s40008019-0174-y.

[18] Matthew OA, Osabohien R, Ogunlusi TO, Edafe O, Agriculture and Social Protection for Poverty Reduction in ECOWAS, Cogent Arts and Humanities, 6(1), 2019, 1682107. https://doi.org/10.1080/23311983.2019.168210 7.

[19] Nagarajan L, Naseem A, Pray C, Contribution of Policy Change on Maize Varietal Development and Yields in Kenya, Journal of Agribusiness in Developing and Emerging Economies,Vol.4, No.2, 2018, pp. 24-38, https://doi.org/10.1108/JADEE-012018-0013.

[20] Osabohien R, Matthew $\mathrm{O}$, Gershon $\mathrm{O}$, Ogunbiyi T, Nwosu E, Agriculture Development, Employment Generation and Poverty Reduction in West Africa. The Open Agriculture Journal, Vol. 13,2019, pp. 82-89.

[21] Clunies-Ross A, Forsyth D, Huq M, Development Economics. 1st ed. Glasgow, UK: Mc-Graw Hill Education. p. 446, 2009.

[22] Pinstrup-Andersen P, World Food Trends and Future Food Security. International Food Policy Research Institute. Agricultural productivity and food security in the developing world, USA: Washington, DC. 1994.

[23] Rosegrant MW, Agcaoili-Sombilla M, Perez ND, Global Food Projections to 2020: Implications for Investment. International Food Policy Research Institute. USA: Washington, DC,1995.

[24] Dethier JJ, Effenberger A, Agriculture and Development. Policy Research Working Paper 5553. Research Support Unit, Development Economics, World Bank, 2011.

[25] Adelman I, Beyond Export-Led Growth. World Development, Vol.12, No.9, 1984, pp. 937- 949.

[26] Matthew O, Osabohien R, Urhie E, Ewetan O, Adediran O, Oduntan E, Olopade C, Agriculture as a stimulant for Sustainable Development in ECOWAS, Sustainability: The Journal of Record, Vol.12, No.4, 2019, pp. 215-225. https://doi.org/10.1089/sus.2018.0039.

[27] Bravo-Ortega C, Lederman D, Agriculture and National Welfare around the World: Causality and International Heterogeneity since 1960. Policy Research Working Paper No. 3499, World Bank, Washington D.C., 2005.

[28] Timmer CP, Agriculture and Economic Development. In Handbook of Agricultural Economics, Vol. 2A, pp.1487-1546, ed. Bruce L. Gardner and Gordon C. Rausser. Amsterdam: North-Holland, 2002.

[29] Osabohien R, Osuagwu E, Osabuohien E, Ekhator-Mobayode UE, Matthew O, Gershon O, Households Access to Agricultural Credit and Agricultural Production in Nigeria: A Propensity Score Matching Model, South African Journal of Economic and Management Sciences, Vol. 23, No.1, 2020, pp. 1-11, a2688. https://doi.org/10.4102/sajems.v23i1.2688.

[30] Osabohien R, Matthew AO, Aderounmu B, Olawande T, Greenhouse Gas Emissions and Crop Production in West Africa: Examining the mitigating potential of Social Protection, International Journal of Energy Economics and Policy, Vol. 9, Issue 1, 2019,pp.57-66, https://doi.org/10.32479/ijeep.7056.

[31] Mellor JW, Faster more equitable growth agriculture, employment multipliers and poverty 
reduction. Research Report prepared for USAID, 2001.

[32] Christiaensen LJ, Demery L, Down to earth: Agriculture and poverty in Africa. Washington D.C.: World Bank, 2007.

[33] Pangaribowo EH, Gerber N, Torero M, Food and nutrition security indicators: A review.ZEF Working Paper No. 108, 2013.http://dx.doi.org/10.2139/ssrn.2237992.

[34] Abbade LPF, Lastória S, de Almeida Rollo H, Ometto SH, A socio-demographic, clinical study of patients with a venous ulcer. International Journal of Dermatology, Vol.44, No.12, 2017, pp.989-992.

[35] Devereux S, why does famine persist in Africa? Food Security, Vol.1, No.1, 2009, pp. 25-35.

\section{Author Contributions:}

Romanus Osabohien, conceived the idea and data analysis

Isaiah Olurinola supervised the work. Oluwatoyin Matthew wrote the introduction and data gathering Amechi Igharo wrote the literature review

Funding Source

The authors appreciate Covenant University Centre for Research, Innovation and Discovery (CUCRID) for funding the publication of this paper.

\section{Creative Commons Attribution License 4.0 (Attribution 4.0 International, CC BY 4.0)}

This article is published under the terms of the Creative Commons Attribution License 4.0

https://creativecommons.org/licenses/by/4.0/deed.en_US 